\title{
VISIT-TO-VISIT BLOOD PRESSURE VARIABILITY AND TARGET ORGAN DAMAGE IN RURAL DWELLERS WITH UNCOMPLICATED ARTERIAL HYPERTENSION
}

10.36740/WLek202012107

\author{
Tetiana I. Nimtsovych ${ }^{1,2}$, Anatolii M. Kravchenko', Olha Yu. Mishcheniuk', Tamara Ya. Chursina ${ }^{3}$, \\ Kyrylo 0. Mikhaliev ${ }^{1}$, Viktor P. Polovyi ${ }^{3}$ \\ 'STATE INSTITUTION OF SCIENCE «RESEARCH AND PRACTICAL CENTER OF PREVENTIVE AND CLINICAL MEDICINE» STATE ADMINISTRATIVE \\ DEPARTMENT, KYIV, UKRAINE \\ ${ }^{2}$ PUBLIC NON-PROFIT ENTERPRISE «KHMELNYTSKYI REGIONAL CARDIOVASCULAR CENTER» KHMELNYTSKYI REGIONAL COUNCIL, KHMELNYTSKYI, UKRAINE \\ ${ }^{3}$ BUKOVINIAN STATE MEDICAL UNIVERSITY, CHERNIVTSI, UKRAINE
}

\begin{abstract}
The aim: To examine the association of hypertensive mediated target organ damage with blood pressure visit-to-visit variability in Ukrainian rural dwellers with uncomplicated hypertension.

Material and methods: The cross-sectional study enrolled 160 adult males with uncomplicated primary hypertension (mean age $50 \pm 6$ yo). We analyzed office systolic and diastolic blood pressure levels, obtained at four consecutive visits. We used standard deviation (SD) value to assess blood pressure visit-to-visit variability. The patients were referred to the group with high ( $n=82 ; 51.3 \%$ ) vs low $(n=78 ; 48.7 \%$ ) blood pressure variability (HBPV, LBPV).

Results: HBPV patients were characterized by higher left ventricular myocardial mass indexed to height 2.7: median, interquartile range: 70.9 (61.3-78.2) vs 50.9 (44.9-54.4) $\mathrm{g} / \mathrm{m} 2.7$, respectively $\mathrm{p}<0.001$. The cases of severe left ventricular hypertrophy prevailed in HBPV group (vs LBPV): $68 \%$ vs $5 \%$, respectively, $p<0.001$. HBPV group was characterized by larger common carotid artery intima-media complex thickness, advanced hypertensive retinopathy, higher urine albumin/creatinine ratio value and worse kidneys' $\mathrm{g}$ lomerular filtration rate. The obtained results might be helpful in the context of global monitoring of vulnerable high risk population of hypertensive rural males.

Conclusions: The HBPV in rural hypertensive males was associated with more pronounced target organ damage. Further regional research on the various clinical aspects of hypertension, including blood pressure variability, might be useful in extending the existed evidence on prevention of hypertension-related complications.
\end{abstract}

KEY WORDS: hypertension, blood pressure, variability, target organ

Wiad Lek. 2020;73(12 p. I):2591-2597

\section{INTRODUCTION}

The negative dynamics of the health indicators of the rural subpopulation, which is almost one third of the total population of Ukraine, merits special attention to the problem of healthcare and health promotion of agricultural workers [1]. Cardiovascular diseases (CVD) are still the leading causes of death in the rural and urban subpopulations of Ukraine. However, CVD mortality in the rural subpopulation exceeds by $42,8 \%$ the corresponding parameter in the urban one, and by $25,9 \%$ - the average mortality rate in Ukraine [2]. Arterial hypertension $(\mathrm{AH})$ is one of the leading CVD risk factors and a major predictor of cardiovascular adverse events. The global prevalence of $\mathrm{AH}$ was estimated to be 1,13 billion in 2015, with a prevalence of over 150 million in Central and Eastern Europe [3]. According to the ESC Cardiovascular Disease Statistics data, higher blood pressure (BP) levels are generally found in Central and Eastern European countries and lower levels in Southern, Western and Northern European countries without a significant positive trend towards decrease [4].
It is worth noting, that virtually all major surveys in the Eastern European region show a significantly higher prevalence of $\mathrm{AH}$ in rural areas [5].

Ukraine has one of the highest rates of CVD morbidity and mortality in the Eastern European region. $\mathrm{AH}$ is a serious public health problem and is one of the leading causes of preventable mortality in Ukraine $[2,6]$. About one third of Ukrainian adults (34\%) have $\mathrm{AH}$, with the age-standardized prevalence of AH being reported as $29,3 \%$ and $36,3 \%$ in urban and rural subpopulations, respectively $[2,7]$. Among hypertensives, $80,8 \%$ of urban dwellers and $67,8 \%$ of rural ones were aware of their condition; $48,4 \%$ and $38,3 \%$, respectively, were receiving any antihypertensive treatment; finally, only $18,7 \%$ and $8,1 \%$, respectively, had their BP controlled. Thus, the rates of $\mathrm{AH}$ awareness, treatment and BP control in Ukraine are still worrisome both in urban and rural areas, especially in the latter one [7].

Existing gaps in the management of patients with $\mathrm{AH}$ may be partly due to a lack of consideration of the phenomenon of BP variability, which is defined as BP fluctuations 
for a certain period of time [8]. It was found the association of BP variability with adverse cardiovascular events, in addition to BP level $[9,10]$. At present, the existing evidence emphasizes the clinical importance of the long-term BP variability - the so-called visit-to-visit variability (VVV) of BP, which is assessed on the basis of data on BP levels at several doctor's visits over a relatively long period of time (weeks, months, years) [10]. For instance, in ASCOT-BPLA study, VVV in systolic BP (SBP) was a strong predictor of stroke and coronary events, independent of mean SBP [10, 11]. It has also been demonstrated the prognostic significance of VVV in diastolic BP (DBP) [9]. Furthermore, a series of studies revealed the association of $\mathrm{BP}$ variability, including $\mathrm{VVV}$, with $\mathrm{AH}$-mediated target organ damage $[12,13]$, although certain aspects of such interactions remain controversial to date [14].

Given the significant burden of CVD in Ukraine, especially in rural areas $[1,2]$, and also well-established association of $\mathrm{AH}$-mediated target organ damage with $\mathrm{AH}$ complications (including cerebrovascular accidents, acute coronary events and heart failure) [3], it would be helpful to assess BP VVV as an additional clinical tool in cardiovascular risk stratification, as well as an additional criterion for evaluating the effectiveness of antihypertensive therapy. Therefore, more work is needed to extend our knowledge as to different clinical and prognostic aspects of $\mathrm{AH}$ in rural dwellers of Ukraine, in particular the association of BP VVV with $\mathrm{AH}$-mediated subclinical target organ damage.

\section{THE AIM}

The aim of the study was to examine the association of target organ damage with BP VVV in rural dwellers with uncomplicated $\mathrm{AH}$.

\section{MATERIAL AND METHODS}

The cross-sectional study retrospectively analyzed clinical, laboratory and instrumental data, derived from consecutive 160 adult males with uncomplicated primary $\mathrm{AH}$ (mean age [mean \pm standard deviation (SD)] $50 \pm 6$ years, the min-max range 39-62 years; $150(93.8 \%)$ patients before the age of 60 years), inhabited in rural areas of Khmelnytskyi region of Ukraine, and enrolled in 2016-2019 at the Public Non-Profit Enterprise «Khmelnytskyi Regional Cardiovascular Center» Khmelnytskyi Regional Council (Khmelnytskyi, Ukraine). The mean AH duration was (median (Me), interquartile range [IQR]) 7 (4-11) years. The study was conducted in accordance with the principles of the Council of Europe Convention on Human Rights and Biomedicine, World Medical Association Declaration of Helsinki on the ethical principles for medical research involving human subjects, and current regulations of the Ministry of Health of Ukraine. The study protocol was approved by the local ethics committee. All patients signed an informed consent to participate in the study. The study did not include patients with complicated primary $\mathrm{AH}$, secondary $\mathrm{AH}$ and diabetes mellitus. Among the enrolled patients, body mass index (BMI) was (Me [IQR]) $27.2(24.8-30.2) \mathrm{kg} / \mathrm{m}^{2}$. $73(45.6 \%)$ patients were overweight (BMI $25.0-25.9 \mathrm{~kg} / \mathrm{m}^{2}$ ), while $41(25.6 \%)$ patients presented with obesity (BMI $\geq 30.0 \mathrm{~kg} / \mathrm{m}^{2}$ ). The smoking status was distributed as follows: never-smoker - 28 (17.5\%), former smoker - 47 (29.4\%), and current smoker - 85 (53.1\%). Laboratory tests were performed in all the patients according to standardized procedures. The mean (Me [IQR]) fasting glucose level was $4.7(4.2-5.0) \mathrm{mmol} / \mathrm{l}$. The mean (Me [IQR]) parameters of lipid profile were as follows: serum cholesterol level - 6.6 (5.5-7.4) $\mathrm{mmol} / \mathrm{l}(156(97,5 \%)$ patients with the level $>4.9$ $\mathrm{mmol} / \mathrm{l}$; $21(13.1 \%)$ patients with the level $>8.0 \mathrm{mmol} / \mathrm{l})$; triglycerides - 2.6 (1.9-3.2) mmol/l (149 (97.5\%) patients with the level $>1.7 \mathrm{mmol} / \mathrm{l})$; low-density lipoproteins (LDL) - $4.7(3.3-5.2) \mathrm{mmol} / \mathrm{l}(153$ (95.6\%) patients with the level $>3.0 \mathrm{mmol} / \mathrm{l})$; and high-density lipoproteins $-1.2(0.9-1.3)$ $\mathrm{mmol} / \mathrm{l}(70(43.8 \%)$ patients with the level $<1.0 \mathrm{mmol} / \mathrm{l})$.

The functional state of the kidneys was assessed by serum creatinine level, estimated glomerular filtration rate (eGFR), and urine albumin/creatinine $(\mathrm{A} / \mathrm{C})$ ratio (in morning spot urine). The urine $\mathrm{A} / \mathrm{C}$ ratio range $3.4-34 \mathrm{mg} / \mathrm{mmol}$ was interpreted as microalbuminuria (MAU), and the level $>34 \mathrm{mg} / \mathrm{mmol}$ was judged as proteinuria. The mean (Me [IQR]) serum creatinine level was 113 (99-119) $\mu \mathrm{mol} / \mathrm{l}$. The CKD-EPI (Chronic Kidney Disease Epidemiology Collaboration) equation [15] was used to calculate eGFR. The mean (Me [IQR]) eGFR was $65(59-75) \mathrm{ml} / \mathrm{min} / 1.73 \mathrm{~m}^{2}$ (min-max range $48-116 \mathrm{ml} / \mathrm{min} / 1.73 \mathrm{~m}^{2}$ ). The distribution of eGFR grades in total sample of enrolled patients was as follows: $\geq 90 \mathrm{ml} / \mathrm{min} / 1.73 \mathrm{~m}^{2}$ - in $8(5.0 \%)$ patients; $89-60$ $\mathrm{ml} / \mathrm{min} / 1.73 \mathrm{~m}^{2}-108$ (67.5\%); and $<60 \mathrm{ml} / \mathrm{min} / 1.73 \mathrm{~m}^{2}-$ 44 (27.5\%). The mean urine A/C ratio (Me [IQR]) was 19.3 $(7.3-30.3) \mathrm{mg} / \mathrm{mmol}$. The vast majority of patients (142 of $160[88.8 \%]$ ) presented with MAU, and $18(11.2 \%)$ patients had proteinuria - urine $\mathrm{A} / \mathrm{C}$ ratio was $36.1-51.3 \mathrm{mg} / \mathrm{mmol}$.

Echocardiography was performed in all the patients by the use of «SONOLINE Versa Pro» scanner (Siemens, Switzerland; 35C40 convex probe 2,6-4,0 MHz), in accordance with the current guidelines of the American Society of Echocardiography (ASE) [16]. Among the parameters we assessed the following ones: left atrial anterior-posterior dimension (LAD), LV end-diastolic dimension (EDD), interventricular septum thickness (IVST), LV posterior wall thickness (PWT) and LV ejection fraction (EF). LV myocardial mass (MM) was calculated by the use of the Devereux «cube» formula (ASE modified) [16]. We indexed LV Mass Myocardium (LV MM) by the height ${ }^{2.7}$ according to $2018 \mathrm{ESC} / \mathrm{ESH}$ guidelines [3]. The mean LV EF (Me [IQR]) in the total sample of enrolled patients was 57\% (55-60\%) (min-max range 45-68\%). The distribution of LV EF grades was as follows: preserved systolic function (LV EF $\geq 50 \%)$ - 155 (96.9\%) patients; midrange LV EF (40-49\%) - 5 (3.1\%) patients.

Duplex scanning of extra cranial carotid arteries (common, external and internal) was performed in all the patients by the use the above mentioned device (75L40 linear probe 7,5 MHz), with the measurement of common carotid artery (CCA) intima-media complex thickness (IMT). The mean (Me [IQR]) right CCA IMT was $1.21(1.13-1.30) \mathrm{mm}$, 
Table I. Baseline clinical characteristics of patients in groups with LBPV and HBPV

\begin{tabular}{cccc}
\hline Parameter & $\begin{array}{c}\text { LBPV } \\
\mathbf{N = 7 8}\end{array}$ & $\begin{array}{c}\text { HBPV } \\
\mathbf{N = 8 2}\end{array}$ & $\mathbf{p}$ \\
\hline Age, years & $50(46-56)$ & $51(45-56)$ & 0.529 \\
\hline HTN duration, years & $4(2-6)$ & $10(7-13)$ & $<0.001$ \\
\hline SBP*, $\mathrm{mm} \mathrm{Hg}$ & $154.5(150.2-161.3)$ & $165.7(161.2-170.7)$ & $<0.001$ \\
\hline SD (SBP), $\mathrm{mm} \mathrm{Hg}$ & $5.5(3.6-8.2)$ & $15.8(15.2-17.3)$ & $<0.001$ \\
\hline DBP*, $\mathrm{mm} \mathrm{Hg}$ & $90.2(84.0-95.7)$ & $93.7(88.5-99.5)$ & $<0.001$ \\
\hline SD (DBP), $\mathrm{mm} \mathrm{Hg}$ & $4.2(3.4-5.8)$ & $10.6(7.3-13.0)$ & $<0.001$ \\
\hline
\end{tabular}

Note: * four visits averaged

Table II. Parameters of structural and functional state of the myocardium in groups with LBPV and HBPV

\begin{tabular}{|c|c|c|c|c|}
\hline \multicolumn{2}{|c|}{ Parameter } & $\begin{array}{l}\text { LBPV } \\
N=78\end{array}$ & $\begin{array}{l}\text { HBPV } \\
\mathrm{N}=82\end{array}$ & $\mathbf{p}$ \\
\hline \multicolumn{2}{|c|}{$\mathrm{LAD}, \mathrm{cm}$} & $3.8(3.4-4.0)$ & $4.1(3.9-4.3)$ & $<0.001$ \\
\hline \multicolumn{2}{|c|}{ LV EDD, cm } & $4.9(4.8-5.2)$ & $5.5(5.2-5.7)$ & $<0.001$ \\
\hline \multicolumn{2}{|c|}{ LV PWT, cm } & $1.20(1.14-1.24)$ & $1.37(1.30-1.42)$ & $<0.001$ \\
\hline \multicolumn{2}{|c|}{ IVST, cm } & $1.23(1.17-1.28)$ & $1.40(1.35-1.49)$ & $<0.001$ \\
\hline \multicolumn{2}{|c|}{ LV MM, g } & $\begin{array}{c}233.3 \\
(216.3-249.7)\end{array}$ & $\begin{array}{c}325.4 \\
(297.9-358.9)\end{array}$ & $<0.001$ \\
\hline \multicolumn{2}{|c|}{ LV MM/h ${ }^{2,7}, \mathrm{~g} / \mathrm{m}^{2,7}$} & $50.9(44.9-54.4)$ & $70.9(61.3-78.2)$ & $<0.001$ \\
\hline \multicolumn{2}{|c|}{ LVH, n (\%) } & $47(60)$ & $82(100)$ & $<0.001$ \\
\hline \multirow{4}{*}{$\begin{array}{c}\text { LVH degree, } \\
\mathrm{n}(\%)\end{array}$} & No LVHz & $31(40)$ & 0 & \multirow{4}{*}{$<0.001$} \\
\hline & Mild $^{z}$ & $31(40)$ & $3(4)$ & \\
\hline & Moderate & $12(15)$ & $23(28)$ & \\
\hline & Severe $^{z}$ & $4(5)$ & $56(68)$ & \\
\hline \multicolumn{2}{|c|}{ LV EF, \% } & $57(56-60)$ & $56(55-59)$ & 0.043 \\
\hline \multirow{2}{*}{$\begin{array}{c}\text { LV EF grades, } \\
\text { n (\%) }\end{array}$} & Preserved $(\geq 50 \%)$ & $76(97)$ & $79(96)$ & \multirow{2}{*}{0.691} \\
\hline & Mid-range (40-49\%) & $2(3)$ & $3(4)$ & \\
\hline
\end{tabular}

Note: $z$ - statistically significant difference by z-test

left CCA IMT - $1.21(1.13-1.31) \mathrm{mm}$. The vast majority of patients (155 of 160 [96.9\%]) presented with bilateral CCA IMT $>0,9 \mathrm{~mm}$. Totally, the carotid stenosis was detected in $148(92,5 \%)$ patients. Among them, $84(56,8 \%)$ patients presented with significant carotid stenosis $(\geq 50 \%)$ [3].

At standard ophthalmic examination (including fundoscopy), the vast majority of patients (155 of 160 [96.9\%]) presented with hypertensive retinopathy, assessed by Keith-Wagener-Barker (KWB) scale [17] (grade 1 - 78 (50.3\%) patients; grade 2 - 77 [49.7\%]).

We retrospectively analyzed the office SBP and DBP levels, obtained at four consecutive doctor's visits (the measurements occurred over the period (Me [IQR]) of 25 (19-34) months). The mean values (Me [IQR]) of SBP and DBP (four visits averaged) were 161.3 (154.1-167.3) $\mathrm{mmHg}$ and 92.0 (86.4-98.0) $\mathrm{mm} \mathrm{Hg}$, respectively. As a metric of BP VVV, we used the SD value, calculated for abovementioned four SBP and DBP levels (SD (SBP) and $\mathrm{SD}$ (DBP), respectively). The patients were referred to the group with high BP variability (HBPV) in case of SD (SBP) $\geq 15 \mathrm{~mm} \mathrm{Hg}$ and/or SD (DBP) $\geq 14 \mathrm{~mm} \mathrm{Hg}[18,19]$. Finally, the total sample of enrolled patients was subdivided into two groups: low BP variability (LBPV) - 78 (48.7\%) patients, and HBPV - 82 (51.3\%). AH-mediated subclinical target organ damages were analyzed according to ESC/ ESH Guidelines criteria $(2013,2018)[3,20]$.

Statistical software programs were used for data analysis (Statistica v. 12.6; IBM SPSS Statistics v.26.0). Continuous variables were presented as $\mathrm{Me}(\mathrm{IQR})$. Categorical variables were presented as absolute and relative (\%) frequency (with $95 \%$ confidence interval (CI) in certain cases). To compare characteristics between LBPV and HBPV groups, we used Mann-Whitney U-test (for continuous variables) and $\chi^{2}$ test or Fisher's exact test (for categorical variables). In case of statistically significant difference in $\chi^{2}$ test, we used $z$-test to compare the frequency of certain categorical variables. $\mathrm{P}<0,05$ was considered statistically significant.

\section{RESULTS}

The groups of patients with LBPV and HBPV were comparable by mean age, with the longer duration of $\mathrm{AH}$ in the 
Table III. Carotid stenotic lesions and common carotid artery intima-media complex thickness in groups with LBPV and HBPV

\begin{tabular}{|c|c|c|c|}
\hline Parameter & $\begin{array}{l}\text { LBPV } \\
N=78\end{array}$ & $\begin{array}{l}\text { HBPV } \\
\mathrm{N}=82\end{array}$ & $\mathbf{p}$ \\
\hline CCA (right), stenosis, n (\%) & $5(6)$ & $18(22)$ & 0.005 \\
\hline CCA (right), stenosis $\geq 50 \%, \mathrm{n}(\%)$ & $2(3)$ & $9(11)$ & $0.057^{*}$ \\
\hline CCA IMT (right), mm & $1.16(1.11-1.21)$ & $1.30(1.21-1.36)$ & $<0.001$ \\
\hline CCA IMT (right) >0,9 mm, n (\%) & $74(95)$ & $81(99)$ & 0.156 \\
\hline CCA (left), stenosis, n (\%) & $16(20)$ & $21(26)$ & 0.445 \\
\hline CCA (left), stenosis $\geq 50 \%, n(\%)$ & $0^{* *}$ & $11^{* * *}(13)$ & 0.001 \\
\hline CCA IMT (left), mm & $1.15(1.09-1.20)$ & $1.30(1.23-1.38)$ & $<0.001$ \\
\hline CCA IMT (left) >0,9 mm, n (\%) & $74(95)$ & $81(99)$ & 0.156 \\
\hline ECA (right), stenosis, n (\%) & $19(24)$ & $24(29)$ & 0.484 \\
\hline ECA (right), stenosis $\geq 50 \%, n$ (\%) & $1(1)$ & $19(23)$ & $<0.001$ \\
\hline ECA (left), stenosis, $n$ (\%) & $18(23)$ & $35(43)$ & 0.008 \\
\hline ECA (left), stenosis $\geq 50 \%, n$ (\%) & $1(1)$ & $27(33)$ & $<0.001$ \\
\hline ICA (right), stenosis, n (\%) & $21(27)$ & $37(45)$ & 0.017 \\
\hline ICA (right), stenosis $\geq 50 \%, \mathrm{n}(\%)$ & $0^{\#}$ & $27^{\# \#(33)}$ & $<0.001$ \\
\hline ICA (left), stenosis, n (\%) & $15(19)$ & $28(34)$ & $0.049^{*}$ \\
\hline ICA (left), stenosis $\geq 50 \%, n(\%)$ & $4(5)$ & $20(24)$ & 0.001 \\
\hline
\end{tabular}

Notes: ECA - external carotid artery; ICA - internal carotid artery; ${ }^{*}-$ Fisher`s exact test; ${ }^{* *}-95 \% \mathrm{Cl}[0-3 \%] ;{ }^{* * *}-95 \% \mathrm{Cl}[7-22 \%]$; $\#-95 \% \mathrm{Cl}[0-$ $3 \%] ; \#$ - 95\% Cl [23-44\%]

Table IV. The presence and degree of hypertensive retinopathy in groups with LBPV and HBPV

\begin{tabular}{ccc}
\hline Parameter & LBPV & HBPV \\
$\mathbf{N}=\mathbf{7 8}$ & $0^{* *}$ & $\mathbf{p}$ \\
\hline No retinopathy & $5\left(6^{*}\right)$ & $22(27)$ \\
\hline Grade $1^{z}$ & $56(72)$ & $60(73)$ \\
\hline Grade $2^{z}$ & $17(22)$ & $<0.001$ \\
\hline
\end{tabular}

Notes: ${ }^{*}-95 \% \mathrm{Cl}[2-13 \%] ;{ }^{* *}-95 \% \mathrm{Cl}[0-2 \%] ; z-$ statistically significant difference by z-test

latter group (Table I). The level of SBP (four visits averaged) was significantly higher in HBPV group, as compared to LBPV group. The difference between the studied groups by DPB (four visits averaged) was also statistically significant, but less pronounced.

After analyzing the echo parameters, we found that HBPV group, in comparison with LBPV group, was characterized by more pronounced structural changes of the myocardium, including higher values of LV MM and LV $\mathrm{MM} / \mathrm{h}^{2.7}$ (Table II). HBPV group was entirely represented by patients with $\mathrm{LVH}$, as opposed to LBPV group $(60 \%$; $\mathrm{p}<0,001)$. The frequency of mild LVH cases was higher in LBPV group, as opposed to the alternative group. Conversely, patients with severe LVH were more prevalent in HBPV group (vs. LBPV group). The frequency of patients with moderate LVH tended to be higher in HBPV group (28\% [95\% CI 19-38\%]), as compared to LBPV group (15\% [95\% CI 8-24\%]) ( $\mathrm{p}=0,054)$. The vast majority of patients in both groups had preserved LV systolic function.

The analysis of parameters, representing the arterial wall damage, revealed higher values of CCA IMT (bilaterally) in HBPV group (vs. LBPV group) (Table III). The cases of the stenosis of right CCA, left external carotid artery and both internal carotid arteries were more frequent in HBPV group. Moreover, HBPV group, as compared to LBPV group, was associated with higher frequency of patients with significant stenotic lesion $(\geq 50 \%)$ of extracranial carotid arteries (except the frequency of right CCA significant stenosis cases, which tended to be higher in HBPV group) (Table III).

At fundoscopy, the HBPV group, as opposed to LBPV group, was characterized by higher frequency of patients with grade 2 of hypertensive retinopathy, assessed by KWB scale (Table IV).

While assessment the renal damage, it was found that HBPV group, as compared to LBPV group, was characterized by worse functional state of the kidneys, namely higher serum creatinine and urine $\mathrm{A} / \mathrm{C}$ ratio value, and lower eGFR (Table V).

It should be noted, that the whole set of 18 proteinuria cases was associated with HBPV. Furthermore, the LBPV group was predominantly represented by patients with eGRF range $60-89 \mathrm{ml} / \mathrm{min} / 1,73 \mathrm{~m}^{2}$. On the contrary, the frequency of patients with more pronounced kidney filtration function impairment (eGFR $<60 \mathrm{ml} / \mathrm{min} / 1,73 \mathrm{~m}^{2}$ ) was higher in HBPV group vs LBPV group $(\mathrm{p}<0.05)$. 
Table V. Parameters of functional state of the kidneys in groups with LBPV and HBPV

\begin{tabular}{|c|c|c|c|c|}
\hline \multicolumn{2}{|c|}{ Parameter } & $\begin{array}{l}\text { LBPV } \\
N=78\end{array}$ & $\begin{array}{l}\text { HBPV } \\
\mathrm{N}=82\end{array}$ & $\mathbf{p}$ \\
\hline \multicolumn{2}{|c|}{ Serum creatinine, $\mu \mathrm{mol} / \mathrm{l}$} & $102(93-111)$ & $119(115-124)$ & $<0.001$ \\
\hline \multicolumn{2}{|c|}{ Urine $\mathrm{A} / \mathrm{C}$ ratio, $\mathrm{mg} / \mathrm{mmol}$} & $7.3(5.5-9.4)$ & $30.2(26.5-33.2)$ & $<0.001$ \\
\hline \multirow{2}{*}{$\begin{array}{c}\text { Degree of } \\
\text { urine A/C ratio, } n(\%)\end{array}$} & MAU & $78(100)$ & $64(78)$ & \multirow{2}{*}{$<0.00$} \\
\hline & Proteinuria & $0 *$ & $18\left(22^{* *}\right)$ & \\
\hline \multicolumn{2}{|c|}{$\mathrm{eGFR}, \mathrm{ml} / \mathrm{min} / 1,73 \mathrm{~m}^{2}$} & $73(66-81)$ & $60(56-64)$ & $<0.001$ \\
\hline \multirow{3}{*}{$\begin{array}{c}\text { eGFR degree, } \mathrm{ml} / \mathrm{min} / 1,73 \mathrm{~m}^{2} \text {, } \\
\mathrm{n}(\%)\end{array}$} & $\geq 90$ & $6(8)$ & $2(2)$ & \multirow{3}{*}{$<0.001$} \\
\hline & $89-60^{z}$ & $69(88)$ & $39(48)$ & \\
\hline & $<60^{z}$ & $3(4)$ & $41(50)$ & \\
\hline
\end{tabular}

Notes: ${ }^{*}-95 \% \mathrm{Cl}[0-3 \%] ;{ }^{* *}-95 \% \mathrm{Cl}[14-32 \%] ; z$ - statistically significant difference by z-test

\section{DISCUSSION}

To date, the problem of $\mathrm{AH}$ among rural dwellers is being actively studied worldwide $[21,22]$. At the same time, there is lack of such studies in Ukraine $[1,23]$. The largest breakpoints were BP monitoring at the frequency recommended by the official guidelines on $\mathrm{AH}$ management $(67 \%$ and $71 \%$ gap in compliance in Lviv and Poltava regions) and achieving normal BP while on treatment $(76 \%$ and $65 \%$ gap among patients with BP monitoring data in Lviv and Poltava regions). Thus, only $24 \%$ in Lviv region and $35 \%$ in Poltava region achieved the BP target [6]. These data are broadly consistent with the global trend in lower middle-income countries [21]. Well known that BP VVV is associated with cardiovascular risk factors [24], AH-mediated target organ damage [12,13,25-27] and major adverse CVD events $[9,10,28]$, thus seems to be of crucially importance at different stages of CVD continuum. The present study, enrolled predominantly young and middle-age males with uncomplicated $\mathrm{AH}$, demonstrated that $\mathrm{HBPV}$ was associated with more pronounced $\mathrm{AH}$-mediated subclinical target organ damage, namely the LV mass index, carotid arteries and kidneys, which was in agreement with other available studies [12, 13, 25-27]. Moreover, HBPV was also associated with more advanced hypertensive retinopathy, that may reflect potential pathophysiological associations of $\mathrm{BP}$ variability with retinal microvascular abnormalities in $\mathrm{AH}[29,30]$. At the same time, the obtained results are worth consideration due to several aspects. Firstly, there are based on the regional real-world data, which might be helpful in the context of global AH monitoring, including the rural areas $[21,22]$. Secondly, based on world and local evidence $[1,6,21,23,31,32]$, rural males with $\mathrm{AH}$ form the vulnerable population in terms of high risk of adverse cardiovascular events. Previous study [1] enrolled the rural dwellers of Ukraine and has revealed significant gender difference in terms of $\mathrm{AH}$ control. Among rural males, there was a much lower awareness of the disease, half the rate of antihypertensive treatment, and nearly five times lower its effectiveness, as compared to females [1]. These results are also compatible with the existed world data [21,22].

In an earlier paper [33] on this problem, we studied the profile of CVD risk factors among the above mentioned patients and revealed the positive correlation of SBP VVV with the SCORE cardiovascular risk value. Bearing in mind the results of the present work, namely the differences between HBPV and LBPV in terms of the certain parameters being studied (LVH, eGFR $<60 \mathrm{ml} / \mathrm{min} / 1.73$ $\mathrm{m}^{2}$ and any carotid stenosis cases, along with CCA IMT value), it is reasonable to suppose that HBPV could be a potential marker of more advanced $\mathrm{AH}$-mediated target organ damage.

\section{CONCLUSIONS}

The HBPV in rural males with uncomplicated $\mathrm{AH}$ was associated with more pronounced subclinical target organ damage (more advanced LVH, carotid arteries wall IMT, worse kidneys' filtration function and higher level of proteinuria). The cases of stenosis and significant stenosis $(\geq 50 \%)$ of the certain external carotid arteries were more frequent among HBPV patients, likewise more advanced hypertensive retinopathy.

Further regional research on the various clinical aspects of $\mathrm{AH}$, including $\mathrm{BP}$ variability, might be useful in extending the existed world evidence on the prevention of $\mathrm{AH}$-related complications. The data should be collected from patients of different age categories, taking into consideration gender aspects, location (urban vs. rural), standard of leaving and CVD risk factors. These activities should be aimed at making timely decisions at the regional level on the organization of medical care, including preventive measures.

\section{REFERENCES}

1. Gorbas I., Smirnova I., Vakalyuk I. et al. Epidemiolohichna sytuatsiia shchodo arterialnoi hipertenzii u silskii populiatsii Ukrainy [Arterial Hypertension Epidemiological Situation Among Rural Population of Ukraine]. Journal «Medicine of Ukraine». 2013;7:88-91. (in Ukrainian).

2. Manoilenko T., Dorokhina A., Tsyzh 0. et al. Stan zdorovia narodu Ukrainy ta medychnoi dopomohy tretynnoho rivnia: posibnyk [Health status of the people of Ukraine and tertiary medical care: a textbook]. Kyiv. 2019: 222. (in Ukrainian).

3. Williams B., Mancia G., Spiering W. et al. 2018 ESC/ESH Guidelines for the management of arterial hypertension. Eur Heart J. 2018;39 (33):30213104. doi: 10.1093/eurheartj/ehy339. 
4. Wilkins E., Wilson L., Wickramasinghe K. et al. European Cardiovascular Disease Statistics 2017. European Heart Network, Brussels. http:// www.ehnheart.org/component/attachments/attachments. html?task=attachment\&id=3115.

5. Ionov M.V., Zvartau N.E., Konradi A.0. Status of hypertension in Russia and Eastern Europe. E-Journal Cardiol Pract. 2019;17(24).

6. Doroshenko 0., Khan 0., Fraser-Hurt N. et al. Hypertension Care in Ukraine: Breakpoints and Implications for Action. Ukraine continuum of care analyses - Breast Cancer, Cervical Cancer, Diabetes, Hypertension. Washington, D.C.: World Bank Group, 2019. http://documents. worldbank.org/curated/en/209221547239438627/ HypertensionCare-in-Ukraine-Breakpoints-and-Implications-for-Action.

7. Svishchenko Y., Bagrii A., lena L. et al. Rekomendatsii Ukrainskoi Asotsiatsii kardiolohiv z profilaktyky ta likuvannia arterialnoii hipertenzii [Guidelines of Ukrainian Society of Cardiology on prevention and treatment of arterial hypertension]. Kyiv: PP VMB. 2008: 80. (in ukrainian).

8. Ostroumova 0.D., Borisova E.V., Pavleeva E.E. Variabelnost arterialnogo davleniya. Mezhvizitnaya variabelnost arterialnogo davleniya. [Blood Pressure Variability. Visit-to-Visit Blood Pressure Variability]. Kardiologiia. 2017;57(11):68-75. doi: 10087/cardio.2017.11.10056. (in Russian).

9. Diaz K.M., Tanner R.M., Falzon L. et al. Visit-to-visit variability of blood pressure and cardiovascular disease and all-cause mortality: a systematic review and meta-analysis. Hypertension. 2014;64(5):965982. doi: 10.1161/HYPERTENSIONAHA.114.03903.

10. Rothwell P.M., Howard S.C., Dolan E. et al. Prognostic significance of visit-to-visit variability, maximum systolic blood pressure and episodic hypertension. Lancet 2010;375(9718):895-905. doi: 10.1016/S01406736(10)60308-X.

11. Rothwell P.M. Limitations of usual pressure hypothesis and the importance of variability, instability and episodic hypertension. Lancet 2010;375(9718):938-948. doi: 10.1016/S0140-6736(10)60309-1.

12. Jeffers B.W.,Zhou D. Relationship Between Visit-to-Visit Blood Pressure Variability (BPV) and Kidney Function in Patients with Hypertension. Kidney Blood Press Res. 2017;42:697-707. doi: 10.1159/000484103.

13. OkadaR.,OkadaA.,OkadaT.etal.Visit-to-visitblood pressure variability is a marker of cardiac diastolic function and carotid atherosclerosis. BMC Cardiovasc Disord. 2014;14:188. doi: 10.1186/1471-2261-14-188.

14. Miyauchi S., Nagai M., Dote K. et al. Visit-to-visit Blood Pressure Variability and Arterial Stiffness: Which Came First: The Chicken or the Egg? Curr Pharm Des. 2019;25(6):685-692. doi: 10.2174/1381612825 666190329122024.

15. KDIGO 2012 Clinical Practice Guideline for the Evaluation and Management of Chronic Kidney Disease. Kidney Int Suppl. 2013;3(1).

16. Lang R.M., Badano L.P., Mor-Avi V. et al. Recommendations for cardiac chamber quantification by echocardiography in adults: an update from the American Society of Echocardiography and the European Association of Cardiovascular Imaging. J Am Soc Echocardiogr. 2015;28(1):1-39.e14. doi: 10.1016/j.echo.2014.10.003.

17. Bokman C.L.,GonzalezM.A.Hypertensive Retinopathy.In:MedinaC, Townsend J, Singh A, eds. Manual of Retinal Diseases. Cham: Springer. 2016: 627-629.

18. Yu Z.B., Li D., Chen X.Y. et al. Association of Visit-to-Visit Variability of Blood Pressure with Cardiovascular Disease among Type 2 Diabetes Mellitus Patients: A Cohort Study. Diabetes Metab J. 2019;43(3):350367. doi: 10.4093/dmj.2018.0108.

19. Rogoza A.N., Agaltsov M.V., Sergeeva M.V. Sutochnoe monitorirovanie arterialnogo davleniya: variantyi vrachebnyih zaklyucheniy i kommentarii [24-Hour blood pressure monitoring: medical opinions and comments]. Nizhniy Novgorod: DEKOM. 2005:63. (in Russian).
20. Mancia G., Fagard R., Narkiewicz K. et al. 2013 ESH/ESC Guidelines for the management of arterial hypertension: The Task Force for the management of arterial hypertension of the European Society of Hypertension (ESH) and of the European Society of Cardiology (ESC). J Hypertens. 2013;31(7):1281-357. doi: 10.1097/01. hjh.0000431740.32696.cc.

21. Chow C.K., Teo K.K., Rangarajan S. et al. Prevalence, awareness, treatment, and control of hypertension in rural and urban communities in high-, middle-, and low-income countries. JAMA. 2013;310(9):959968. doi: 10.1001/jama.2013.184182.

22. Harrington R.A., Califf R.M., Balamurugan A. et al. Call to Action: Rural Health: A Presidential Advisory From the American Heart Association and American Stroke Association. Circulation. 2020;141:e615-e644. doi: CIR.0000000000000753.

23. Lashkul Z.V. Osoblyvosti epidemiolohii arterialnoi hipertenzii ta yii uskladnen na rehionalnomu rivni z 1999 po 2013 roky [Features epidemiology of hypertension and its complications at the regional level in 1999-2013]. Modern medical technologies. 2014;2:134-141. (in Ukrainian).

24. Boev S.S., Dotsenko N.Y., Gerasimenko L.V. et al. Aktualni aspekty variabelnosti arterialnoho tysku pry arterialnii hipertenzii [Actual aspects of blood pressure variability in arterial hypertension]. Journal «Hypertension». 2018;2(58):44-51. doi: 10.22141/22241485.2.58.2018.131065. (in Ukrainian).

25. Mehlum M.H., Liestøl K., Kjeldsen S.E. et al. Blood pressure variability and risk of cardiovascular events and death in patients with hypertension and different baseline risks. Eur Heart J. 2018;39(24):2243-2251. doi: 10.1093/eurheartj/ehx760.

26. KawaiT., Ohishi M., Kamide K. et al. The impact of visit-to-visit variability in blood pressure on renal function. Hypertens Res. 2012;35(2):239243. doi: $10.1038 / \mathrm{hr} .2011 .170$.

27. Chi X., Li M., Zhan X. et al. Relationship between carotid artery sclerosis and blood pressure variability in essential hypertension patients. Comput Biol Med. 2018;92:73-77. doi: 10.1016/j.compbiomed.2017.03.012.

28. Hoshide S. Clinical implication of visit-to-visit blood pressure variability. Hypertens Res. 2018;41(12):993-999. doi: 10.1038/s41440-018-01074.

29. Shin S.H., Jang J.H., Baek Y.S. et al. Relation of blood pressure variability to left ventricular function and arterial stiffness in hypertensive patients. Singapore Med J. 2019;60(8):427-431. doi: 10.11622/ smedj.2019030.

30. Triantafyllou A., Anyfanti P., Gavriilaki E. et al. Association between retinal vessel caliber and arterial stiffness in a population comprised of normotensive to early-stage hypertensive individuals. Am J Hypertens. 2014;27(12):1472-1478. doi: 10.1093/ajh/hpu074.

31. Sydorchuk L., Yarynych Y., Knut R. et al. Hepatocytes' Function and Adipokines in Patients with Non-alcoholic Fatty Liver Disease Depending on the ACE (rs4646994) and PPAR-g2 (rs1801282) Genes' Polymorphisms. Rev Med Chir Soc Med Nat lasi. 2018;122(2):358-364.

32. Hetmaniuk I.B., Fedoniuk L. Ya., Zhulkevych I. V., Andreychyn S. M., et al. Microscopic and submicroscopic structure of the heart atria and auricles in condition of the experimental thermal trauma. Biointerface Research in Applied Chemistry. 2020; 10 (2): 5237-5242.

33. Nimtsovych T.I., Mischeniuk 0.Y., Kravchenko A.M. Faktory sertsevosudynnoho ryzyku ta mizhvizytna variatyvnist arterialnoho tysku [Factors of cardiovascular risk and intervisit arterial pressure variability]. Clinical and Preventive Medicine. 2019;1(7):17-24. doi: 10.31612/26164868.1(7).2019.03. 
The study was conducted as a fragment of the complex scientific projects of the Scientific Department of Internal Medicine (State Institution of Science "Research and Practical Center of Preventive and Clinical Medicine» State Administrative Department) "Development and improvement of methods of prevention of complications of arterial hypertension and ischemic heart disease, associated with internal diseases, in civil servants» (state registration number 0114U002119; term: 2014-2018) and "Improvement of prevention, treatment and rehabilitation of patients with arterial hypertension and coronary heart disease with comorbid pathology in outpatient and inpatient settings» (state registration number 0119U001045; term: 2019-2021).

\section{ORCID and contributionship:}

Tetiana I. Nimtsovych: 0000-0001-7472-9361 ${ }^{\text {A, B, C, D }}$

Olha Yu. Mishcheniuk: 0000-0002-5306-4716 B, C,D

Kyrylo O. Mikhaliev: 0000-0003-3759-6699 ${ }^{\text {B, C }}$

Anatolii M. Kravchenko: 0000-0001-6863-0197 A, D, E, F

Tamara Ya. Chursina: 0000-0001-8566-9587 E, F

Viktor P. Polovyi: 0000-0002-4345-9802 E, F

\section{Conflict of interest:}

The Authors declare no conflict of interest.

\section{CORRESPONDING AUTHOR}

Viktor P. Polovyi

Department of General Surgery

Bukovinian State Medical University

2 Teatralna sq., 58002 Chernivtsi, Ukraine

tel.: +380954132678

e-mail:doctorvictor@i.ua

Received: 17.07 .2020

Accepted: 19.11 .2020

A - Work concept and design, B - Data collection and analysis, C - Responsibility for statistical analysis,

D -Writing the article, $\mathbf{E}$ - Critical review, $\mathbf{F}$ - Final approval of the article 